\title{
A Review of Occupational Disease Certification Criteria for Noise-Induced Hearing Impairment
}

\author{
KyooSang Kim \\ Occupational Environmental Medicine, Seoul Medical Center, Seoul, Korea
}

소음성 난청의 업무상 질병 인정기준 고찰

김 규 상

서울특별시 서울의료원 직업환경의학과

\begin{abstract}
Noise-induced hearing impairment is bilateral sensorineural hearing loss that typically occurs with high degrees of hearing impairment in the high-frequency range of 3-6 kHz. Certification of noise-induced hearing impairment as an occupational disease is legislated according to the following criteria: 1) three years of exposure to noise at a level of $85 \mathrm{~dB}(\mathrm{~A})$; 2) sensorineural hearing loss with no air-bone hearing gap; and 3) hearing loss that is not age-related. In particular, although the direct impact of noise is recognized, it is difficult to distinguish the effects of noise-induced hearing impairment from those of presbycusis. Therefore, recognition of noise-induced hearing impairment and its relevance as an occupational disease may be overlooked. Furthermore, if someone is moved to a noise-free work area [below $85 \mathrm{~dB}(\mathrm{~A})$ ], application for workers' injury compensation would be disapproved after 3 years because of the expiration of the validity period. However, based on a recent Supreme Court precedent, expiration of the validity period for the right to claim benefits was recently changed to the date of confirmed diagnosis of hearing impairment. This study examines the occupational disease certification criteria for noise-induced hearing impairment and the judgment of occupational diseases. Specifically, we discuss and make suggestions regarding noise exposure standards and assessment methods, used as legal evidence in this area. We also discuss assessments of hearing loss type in order to evaluate the status of noise-induced hearing loss as an occupational disease, and the various issues resulting from occupational hazard claims.
\end{abstract}

Key Words: Noise, Noise-induced hearing impairment, Noise exposure standards, Noise exposure assessment, Age-related hearing loss.

Received: May 8, 2017 / Revised: May 31, 2017 / Accepted: June 2, 2017

Correspondence: KyooSang Kim, Occupational Environmental Medicine, Seoul Medical Center, 156 Sinnae-ro, Jungnang-gu, Seoul 02053, Korea Tel: +82-2-2276-7755 / Fax: +82-2-2276-7438 / E-mail: kyoosang@daum.net

\section{INTRODUCTION}

소음성 난청은 전형적으로 양측성 난청으로, 초기에는 3,4 , $6 \mathrm{kHz}$ 의 청력역치에서 노치(notch), 즉 청력이 급격히 나빠져 V자형 순음청력도로 나타나며 $8 \mathrm{kHz}$ 청력은 상대적으로 양호 하다. 반면, 노인성 난청은 전형적인 노치가 없다. 노인성 난청이 없는 소음성 난청은 저주파역에서는 $40 \mathrm{~dB} \mathrm{HL}$ 이하의 경도 난 청을 보이며, 고주파역에서 심한 난청 소견을 보인다. 기간 경과 에 따라 소음성 난청의 진행은 느려지고 노인성 난청의 진행은 가속화된다. 매일 $85 \mathrm{~dB}(\mathrm{~A})$ 이상의 소음에 노출될 경우 노출 강 도가 클수록 소음성 난청의 위험도가 증가한다. 영구적인 청력 역치 변화에 앞서 일시적인 역치 변화가 선행한다(ACOEM, 2012). 소음성 난청으로 생각하기 어려운 순음청력도의 유형으
로는 주파수와 관계없이 편평한 형태의 난청, 고주파보다 저주파 청력이 더 나쁜 경우, 특히 50세 미만의 근로자가 $70 \mathrm{~dB} \mathrm{HL}$ 이상 의 고도 난청 혹은 농일 경우, 청력역치 변화가 매우 심할 때, 좌. 우측 난청의 정도 차이가 매우 클 때를 제시하고 있다(National Hearing Conservation Association, 2011).

우리나라의 산업재해보상보험법에서 소음성 난청의 업무상 질병 인정기준(업무상 질병에 대한 구체적인 인정기준; 제34조 제3항 관련 [별표3], 개정 2016.3.22.)은 연속음으로 $85 \mathrm{~dB}$ (A) 이상의 소음에 노출되는 작업장에서 3년 이상 종사하거나 종사 한 경력이 있는 근로자로서 한 귀의 청력손실이 6분법으로 40 $\mathrm{dB} \mathrm{HL}$ 이상이 되는 감각신경성 난청의 증상 또는 소견이 다음 과 같은 요건을 충족할 것을 정하고 있다. 1) 고막 또는 중이에 뚜렷한 병변이 없을 것, 2) 순음청력검사 결과 기도 청력역치와 
골도 청력역치 사이에 뚜렷한 차이가 없어야 하며, 청력장해가 저음역보다 고음역에서 클 것, 3) 내이염·약물중독·열성 질환· 메니에르씨 증후군·매독·두부외상·돌발성 난청·유전성 난청· 가족성 난청·노인성 난청 또는 재해성 폭발음 등에 의한 난청 이 아닐 것. 이와 같이 소음성 난청은 노출 소음 수준, 노출 기 간, 청력손실의 최저기준, 난청의 유형 및 배제해야 할 이(귀) 질 환을 인정기준에 제시하고 있다. 근로복지공단의 실무적인 차 원에서 요양 신청 대상의 여부와 업무상 질병의 판단에서 1) 산 업위생학적으로 소음 노출의 위험성이 없다는 판단에서 배제된 경우로 가) 비소음부서로 작업 전환되어 장기간이 지나거나, 나) 작업환경 측정 대상 작업장인 강렬한 소음이 발생되는 옥 내 작업장에 해당되지 않아 작업환경 측정을 전혀 하지 않거나 노출 수준의 확인이 불가능하여, 다) 소음에 대한 작업환경 측 정이 이루어졌다 하더라도 연속음으로 $85 \mathrm{~dB}(\mathrm{~A})$ 이하인 경우 에 일차적으로 업무상 질병으로서 소음성 난청의 위험성을 낮 게 보는 경우가 많다. 그리고 2) 의학적으로 소음성 난청의 인정 기준에 미치지 못한 경우로 가) 소음에 노출되는 작업장에서 3 년 이상 종사하지 않은 경우 발생한 소음성 난청, 나) 한 귀의 청 력손실이 $40 \mathrm{~dB} \mathrm{HL}$ 이상이 되는 감각신경성 난청으로서 순음 청력검사 결과 기도 청력역치와 골도 청력역치 사이에 뚜렷한 차이가 없어야 하나 소음에 의한 감각신경성 난청과 비직업적인 난청, 특히 중이염 등 전음성 난청과의 병합에 따른 혼합성 난청 장해, 다) 소음의 직력이 인정됨에도 소음성 난청과 고연령으로 인한 노인성 난청의 영향을 구분하기 어려워 소음성 난청의 인 정 등 업무상 질병으로서 관련성을 무시할 수 있다. 그러나 인 정기준은 예시규정으로 그 기준에서 정한 것 외에 업무와 관련 하여 발생한 질병을 모두 업무상 질병에서 배제하는 규정으로 볼 수 없다. 그리고 마지막으로 장해 급여 청구권의 발생과 관 련하여 난청이 유발되는 작업장을 떠난 때로부터 3년의 소멸시 효와 이후 대법원 판례에 따른 난청의 확진일로 바뀐 데에 따른 문제점을 고찰할 필요가 있다.

이 연구는 산업재해보상보험법의 소음성 난청의 업무상 질병 인정기준과 업무상 질병의 판정 및 장해 판정과 관련한 법적 근 거로써 소음 노출기준과 소음 노출 평가방법, 소음성 난청의 업 무상 질병의 판정을 위한 난청의 유형 평가 및 장해 급여 청구 에 따른 제반 문제에 대해 고찰하고 제언하고자 한다.

\section{REVIEW ON OCCUPATIONAL DISEASE STANDARD OF NOISE-INDUCED HEARING LOSS}

\section{소음 노출기준과 소음 노출 평가}

우리나라의 소음 노출기준은 연속음인 경우 8시간 노출기준
으로 $90 \mathrm{~dB}(\mathrm{~A})$ 이며, $115 \mathrm{~dB}(\mathrm{~A})$ 를 초과하는 소음에 노출되어 서는 안 되며, 최대음압 수준이 $120 \mathrm{~dB}(\mathrm{~A})$ 이상인 소음이 1초 이상의 간격으로 발생하는 충격소음의 경우에서는 1 일 노출 횟 수로 규정하고, $140 \mathrm{~dB}(\mathrm{~A})$ 를 초과해 노출되어서는 안 된다고 규정하고 있다(화학물질 및 물리적 인자의 노출기준, 고용노동 부 고시 제2016-41호). 물리적 인자로서 작업장 소음은 8시간 시간가중평균 $80 \mathrm{~dB}(\mathrm{~A})$ 이상의 소음은 작업환경 측정 대상 유 해인자로서 6 개월에 1 회 이상 정기적으로 작업환경을 측정하여 야 한다. 다만, 작업공정 내 소음의 작업환경 측정 결과가 최근 2 회 연속 $85 \mathrm{~dB}(\mathrm{~A})$ 미만인 경우 1년에 1회 이상 작업환경 측정 을 할 수 있다(산업안전보건법 시행규칙 제93조의4).

노출기준으로 시간가중평균 노출기준(1일 8시간 작업을 기 준으로 하여 측정치에 발생 시간을 곱하여 8시간으로 나눈 값), 단시간노출기준(15분간의 시간가중평균 노출값), 최고노출기준 (근로자가 1 일 작업 시간 동안 잠시라도 노출되어서는 안 되는 기준)을 적용하며, 소음 노출과 관련하여 적용하면 8시간 시간 가중평균 노출기준은 $90 \mathrm{~dB}(\mathrm{~A})$, 단시간노출기준은 $115 \mathrm{~dB}(\mathrm{~A})$, 최고노출기준은 $140 \mathrm{~dB}(\mathrm{~A})$ 로 볼 수 있다. 측정은 단위작업장소 (작업환경 측정 대상이 되는 작업장 또는 공정에서 정상적인 작 업을 수행하는 동일 노출 집단의 근로자가 작업을 하는 장소)에 대해 1 일 작업 시간 동안 6 시간 이상 연속 측정하거나 작업 시 간을 등간격으로 나누어 6시간 이상 연속 분리하여 측정한다. 다만, 소음의 발생 특성에 따라 연속음으로서 측정치가 변동이 없다고 판단한 경우에는 1 시간 동안을 등간격으로 나누어 3 회 이상 측정할 수 있으며, 단위작업장소에서의 소음 발생 시간이 6 시간 이내인 경우나 소음 발생원에서의 발생 시간이 간헐적인 경 우에는 발생 시간 동안 연속 측정하거나 등간격으로 나누어 4 회 이상 측정한다. 그리고 단위작업장소에서 모든 작업자에 대 해 개인 측정을 시행하지 않고 매 5 명당 1 명(1개 지점)으로 개인 과 지역시료채취방법으로 동시 측정한다. 소음 측정의 청감보정 회로는 $\mathrm{A}$ 특성으로 하고 누적소음 노출량 측정기로 소음을 측 정하는 경우에는 허용기준(criteria level)은 $90 \mathrm{~dB}$, 교환율(exchange rate)은 $5 \mathrm{~dB}$, 역치값(threshold level)은 $80 \mathrm{~dB}$ 로 기기를 설정하고, 소음이 1 초 이상의 간격을 유지하면서 최대음압 수준 이 $120 \mathrm{~dB}(\mathrm{~A})$ 이상의 소음인 경우에는 소음 수준에 따른 1 분 동안의 발생 횟수를 측정한다(작업환경 측정 및 지정측정기관 평가 등에 관한 고시, 고용노동부고시, 제2016-39호).

우리나라 업무상 질병으로서 소음성 난청 적용상의 소음 노 출기준과 소음 측정 방법 및 소음 노출 평가에 대해 몇 가지 문 제점을 갖고 있다. 우선 노출기준으로 연속음의 경우 8시간 90 $\mathrm{dB}(\mathrm{A})$ 의 노출기준, $5 \mathrm{~dB}$ 의 교환율, 충격음의 경우 최대음압 수 준 $140 \mathrm{~dB}(\mathrm{~A})$, 음압 수준별 노출기준을 1 일 노출 횟수로 규정 하고 있으나 국제적인 권고기준이나 여러 나라의 소음 노출기 
준과 비교하여 보면 높게 정하고 있다는 것을 알 수 있다. 140 $\mathrm{dB} \mathrm{SPL}$ 을 초과할 경우, 단 한 번의 노출로도 와우 손상으로 인해 청력역치가 상승될 수 있는 위험한 수준의 소리이다(Savolainen \& Lehtomäki, 1997; Ylikoski, 1989).

미국 산업안전보건연구원(National Institute for Occupational Safety and Health, NIOSH)은 소리의 동일 에너지 법칙을 적용 하여 그 소음 형태가 연속음이든, 충격음이든 모든 소음 노출 에 대해 8 시간 $85 \mathrm{~dB}(\mathrm{~A})$ 와 $3 \mathrm{~dB}$ 교환율과 $140 \mathrm{~dB}(\mathrm{~A})$ 의 최대 치 제한값(ceiling limit)의 권장 노출기준(Recommended Exposure Limit)을 제시하고 있다(NIOSH, 1998). 일반적으로 충 격음에 대한 측정 평가방법으로 최대치와 총 에너지 평가방법 등 두 가지가 제시되고 있으며, 이에 따른 노출기준으로 프랑스 는 A 보정 최대치로 $135 \mathrm{~dB}$, 영국은 C 보정치로 $140 \mathrm{~dB}$, 유럽 은 노출 수에 상관없이 $140 \mathrm{~dB} \mathrm{SPL}$, 미국산업위생전문가협회 (American Conference of Governmental Industrial Hygienists)는 C 보정 최대치로 $140 \mathrm{~dB}$ 을 초과해서 노출되지 않도록 권고하고 있다. 충격음에 대해 $\mathrm{C}$ 보정 또는 무보정(dB SPL)보 다 A 보정방법으로 측정한 경우, 소음계 지시침의 반응속도를 일반적으로 연속음 측정 시의 느린(slow) 상태로 측정한 경우 에는 충격음의 최고값(peak)으로 측정한 값보다 소음 노출 수 준에 대해 저평가될 가능성이 크다. 그리고 충격음의 노출 수 준에 따른 노출 횟수로 평가 적용하기가 현실적으로 어려운 측 면이 있다. 따라서 충격음의 노출기준으로는 노출 횟수가 아닌 최고노출기준(Ceiling, C)을 설정하고, 측정방법으로는 최고 소음도를 고려한 등가소음도(C 보정 또는 무보정)로 측정 평가 할 필요가 있다.

노출기준에서 노출 시간 보정은 1 일 작업 시간 동안 연속 측 정하거나 시간 간격으로 측정한 경우 이를 평균하여 8시간 작업 시의 평균소음 수준으로 제시하는 것은 작업장의 소음 수준을 평가하고 이를 개선하는 방법으로 타당하나, 소음에 노출되는 근로자의 경우에는 타당하지 않다. 즉, 작업자의 소음 노출은 일 8시간이 아닌 주 40 시간 기준, 그리고 더불어 당해 사업장의 소음 노출 근로자 실제 근무 시간을 적용하여 보정한 소음 노출 수준을 가지고 판단되어야 한다. 더구나 우리나라 근로자는 대 체적으로 장시간 근로를 수행하고 있다는 점에서 이는 고려하 여야 할 부분이다.

소음에 노출되는 작업부서 전체 근로자에 대한 특수건강진 단 주기는 2 년에 1 회 이상, 당해 건강진단 직전의 작업환경 측정 결과 소음이 노출기준 이상인 경우와 소음에 의한 직업병 유소 견자가 발견된 경우에는 기본 주기를 다음 회에 한하여 $1 / 2$ 로 단축한다(근로자건강진단 실무지침, 2016-연구원-276). 작업장 의 8 시간 시간가중평균 $80 \mathrm{~dB}(\mathrm{~A})$ 이상의 소음은 작업환경 측 정 대상 유해인자이나 소음 특수건강진단 대상은 $85 \mathrm{~dB}(\mathrm{~A})$ 이
상 노출되는 근로자이다. 그리고 이와 같은 $85 \mathrm{~dB}(\mathrm{~A})$ 이상 소 음에 노출되는 작업장에서 3년 이상 종사하거나 종사한 경력이 있는 자에 한해 업무상 질병으로서 소음성 난청을 제한하고 있 다. 이처럼 작업장의 소음이 $85 \mathrm{~dB}(\mathrm{~A})$ 미만이면 당해 근로자는 소음 특수건강진단의 대상이 되지 못하고 또한 아무리 오랜 기 간 노출되었다 하더라도 $85 \mathrm{~dB}$ (A)에 미치지 못하면 업무상 질 병으로서 소음성 난청을 배제(불인정)하고 있다. 현재의 소음 노 출 수준으로 과거의 소음에 의한 청력손실을 평가하는 데 있어 문제는 단순한 노출 수준만이 아니고 소음에 의한 청력 영향은 장기적인 노출에 따른 만성적이고 비가역적인 변화로 나타나기 때문에 적어도 소음에 의한 난청 영향이 미치지 못하는 수준인 $80 \mathrm{~dB}$ 미만이 아니라면 $80 \mathrm{~dB}$ 이상의 소음 누적 노출량의 관점 에서 평가되어야 한다. 더구나 과거의 작업환경은 현재에 비해 열악하고 또한 더 오랜 작업 시간 근로를 수행하였으나 이의 기 록이 부실한 상태이기 때문이다.

소음성 난청의 발생 요인으로서 노출 소음의 강도와 노출 기 간이 가장 중요하다. 일반적으로 $85 \mathrm{~dB}(\mathrm{~A})$ 이상의 소음에 장기 간 노출되면 손상을 받을 잠재성이 있으며, $80 \mathrm{~dB}(\mathrm{~A})$ 이하 소 음의 청력손실 효과는 무시할 수 있다고 한다. 평균 $80 \mathrm{~dB}(\mathrm{~A})$ 에 40년간 노출되었을 때 평균 청력이 $25 \mathrm{~dB}$ 이상의 소음성 난 청의 발생 위험률을 추정하면 국제표준기구(International Organization for Standardization, ISO)는 0\%, 미국 환경보호국 (Environmental Protection Agency, EPA)은 5\%, NIOSH는 $3 \%$ 를 추정하고 있으며, $85 \mathrm{~dB}(\mathrm{~A})$ 에 노출되는 경우에는 ISO $10 \%, \mathrm{EPA}, 12 \%, \mathrm{NIOSH}$ 는 $15 \%$ 정도의 평균 $25 \mathrm{~dB}$ 이상의 소음 성 난청 유병률을, $90 \mathrm{~dB}(\mathrm{~A})$ 에 노출되는 경우에 있어서는 ISO $21 \%$, EPA $22 \%$, NIOSH 29\%를 추정하고 있다.

실제 $85 \mathrm{~dB}(\mathrm{~A})$ 이하의 소음 수준에 노출된 임업 종사자에서 상당히 많은 비율의 소음성 난청이 의심되는 결과를 보고하며, 고용 시의 청력, 진동이나 일산화탄소 및 살충제 등의 환경 노 출에 따른 소음성 난청의 악화나 기여, $85 \mathrm{~dB}$ (A) 미만 근로자 에서 소음에 대한 과소평가로 청력보호구의 미착용 등이 영향 을 미쳤을 것으로 보았다(Lacerda et al., 2015). 또 일시적 난청 이 발생하지 않는다면 영구적 청력장애도 발생하지 않는다고 볼 때, 75 80 dB (A)의 24시간 소음 노출로 인한 일시적 난청의 발 생과 회복을 보이며, 특히 $4 \mathrm{KHz}$ 에서 청력손실이 민감하게 관찰 되고 예측할 수 있는 연구 보고도 있어(Stephenson et al., 1980), $85 \mathrm{~dB}(\mathrm{~A})$ 에 미치지 못한다 하더라도 제반 직업력과 소음 노출 력을 고려해 접근하여야 할 것이다. 그러나 $85 \mathrm{~dB}(\mathrm{~A})$ 에 미치지 못하면 연령 보정한 표준역치 변동량이 대부분 $10 \mathrm{~dB}$ 을 보일 뿐이고(Rabinowitz et al., 2007), 소음이 $85 \mathrm{~dB}$ (A) 미만인 근 로자는 과거의 상당한 소음 노출과 청력손실이 있는 근로자에 서도 고주파역의 난청 위험과 관련이 없다는 점에서(Rabi- 
nowitz et al., 2013) $85 \mathrm{~dB}$ (A) 이하의 노출에서 소음성 난청은 일반적이지는 않다.

사업장의 소음은 동일 작업부서에서도 소음의 측정 시기, 측 정 방법, 측정 장소 등에 따라서 다르게 측정되어질 뿐만 아니 라 근로자 개인의 작업 당시의 상황 즉, 작업의 강도, 작업의 횟 수 및 개인의 숙련도 등에 따라서 개인 노출량이 다르므로 지시 소음계를 이용한 환경 소음보다는 개인 소음 노출량을 측정하 는 것이 효율적으로 알려져 있다(Shim et al., 1995). 그러므로 소음 부서에 근무하는 근로자들의 청력손실 정도를 평가함에 있어서 중요한 요인인 소음 노출량의 측정 시 여러 요건을 고려 하지 않고 작업환경 소음을 일률적으로 적용한다면 부서에 따 라서는 개인 소음 노출량보다 낮게 평가되어 소음으로 인한 청 력손실이 있는 근로자를 간과하기 쉽다. 일반적으로 개인은 소 음원인 기기에 근접하여 작업하기 때문에 개인 소음 측정치가 지역 소음 측정보다 높은 경향이 있다. 따라서 비록 환경 소음 이 낮게 평가되는 부서라도 개인 소음 측정계를 이용하여 개인 소음 노출량을 측정하거나 충격음의 경우 이와 같이 소음 특성 을 고려한 측정 평가방법을 통하여 소음 특수건강진단 대상자 를 선정하거나 소음성 난청의 판정 시에 주의하여야 한다.

\section{난청의 유형}

업무상 질병으로서 소음성 난청은 기도 청력역치와 골도 청 력역치 사이에 뚜렷한 차이가 없는 감각신경성 난청으로 청력 손실이 6분법으로 $40 \mathrm{~dB} \mathrm{HL}$ 이상으로 정하고 있어 혼합성 난 청이 배제되고 또 감각신경성 난청의 한 유형인 돌발성 난청이 나 노인성 난청도 소음과 관련이 없는 질환으로 배제되고 있다.

혼합성 난청은 전음성과 감각신경성 장애가 공존하는 것을 말한다. 일례로 이경화증(otosclerosis)과 같은 전음성 난청으로 부터 출발하여 후에 감각신경성 청력 장애가 잇달아 나타난 경 우라든지 또는 노인성 난청과 같은 감각신경성 청력 장애가 있 는 자에서 중이염과 같은 전음성 난청이 발생한 경우에서 혼합 성 난청의 청력 장애 유형을 보인다. 그리고 심한 두부외상의 경우에서는 내이와 중이 장해로 인해 전음성 및 감각신경성 청 력 장애가 동시에 나타날 수 있다.

현재의 소음성 난청 인정기준은 중이에 뚜렷한 병변이 있는 경우를 제외하고 있어 소음에 의한 난청이 진행하여 소음 노출 전후의 중이 질환과 병합되어 나타날 수 있는 혼합성 난청을 배 제하고 있다. 그러나 노출 유해요인에 의해 이환된 의학적으로 인정되는 질환만 아니라 기초 질환 또는 기존 질병이 있는 근로 자의 경우 그 질환 또는 질병이 자연발생적으로 나타난 증상이 아닌 악화 진행되어 나타났다면 이도 직업성 질환으로서 업무 상 질병의 범주에 포함시키고 있다.

이와 같은 직업성 난청으로서 혼합성 난청은 지속적인 소음
노출 결과로 인한 전형적인 소음성 난청 장애라기 보다는 전음 성 난청 장애에 소음으로 인한 감각신경성 난청이 병합된 난청 이다(Kim et al., 2002; Kim et al., 2011). 감각신경성 난청 부분 (골도역치)이 소음성 난청의 특징을 보이며 업무에 기인하는 것 으로 판단되는 경우 당해 감각신경성 난청에 대해 업무상 질병 으로 보아도 될 것이다. 물론 직업적 요인인 소음으로 인한 장애 정도의 판단은 개인적 요인인 전음성 난청으로서의 중이염 등과 관련하여 귀의 장해 등급상의 기도 청력손실치를 적용할 수 없 을 것이나, 소음으로 인한 청력손실을 내이의 영향을 보여주는 골도 청력역치로 산정할 수 있을 것이다. 다만, 전음성 난청 귀 는 반대측 귀에 비해 고음역의 청력손실이 작아 소음으로 인한 소음성 난청의 예방적 효과도 있다(Park et al., 2016).

소음으로 인한 청력손실은 지속적인 소음의 노출로 인해 서 서히 진행되는 소음성 난청과 매우 강력한 음에 순간적으로 노출 되어 나타나는 급성 음향 외상에 의해 돌발적으로 나타난 청력 손실로 나눌 수 있다. 소음에 의한 돌발성 난청으로는 Kawata \& Suga(1967)가 단일한 강력한 소음에 노출된 일정 시간 후 급작 스럽게 발생한 농형 청력손실을 보고하였다. 대부분 일측성으로 발생하며 청력손실의 형태는 U자형 또는 수평 형태였다. 직업적 인 감각신경성 돌발성 난청의 발생 원인으로는 잠수부 또는 비 행사의 압력상해 및 음향외상을 보고하고 있으며, 이는 대부분 난원창 및 정원창 막의 누공 형성과 관련되고 있다(Lyons et al., 1978; Pullen et al., 1979).

음향외상성 난청의 발생기전은 강력한 소음의 노출로 인한 내이의 손상(특히 기저막 파열, 개막 파열, 유모세포 손상 등의 코티기관의 손상)으로 돌발적 또는 일시적으로 감각신경성 난 청을 초래한다. 청력손실의 형태는 소음성 난청의 형태와 비슷 한 고음역 손실(high-frequency dip)을 보인다. 폭발음에 노출 된 경우에는 고막 손상이나 이소골 연쇄의 손상을 일으켜 전음 성 난청 혹은 혼합성 난청을 초래할 수 있다. 그러나 충격음이나 폭발음과 같은 높은 소음 수준에 갑자기 노출되어 발생하는 음 향외상성 난청과 달리 평소 소음에 계속적으로 노출되었으나 어느 순간 노출 소음의 강도가 증가되던지 소음 노출하의 체위 변화에 의해서 야기되는 돌발적인 청력손실이 있을 수 있다. 즉, 소음성 난청이 발생하는 정도의 소음 수준에서도 돌발적으로 난청이 발생할 수 있다(Kim et al., 1998; Kim et al., 2011). 일반 적인 돌발성 난청은 주로 기상 시에 발생하고, 소음으로 인한 돌 발성 난청은 소음 작업 중에 발생하는 발생 시점의 차이로 구분 하나, 발생 시점의 차이는 근거가 부족하다.

난청 유형(감각신경성 난청), 제외 난청 질환(돌발성 난청, 노 인성 난청) 등의 소음성 난청 업무상 질병 인정기준의 엄격한 적용에 따라 위와 같은 비전형적인 난청은 업무상 질병으로서 불인정될 가능성이 많다. 따라서 근로자의 과거 병력과 소음으 
로 인한 청력 장애의 특성 등 제반 사항을 고려하여 업무상 질 병으로서 판단할 수 있는 소음성 난청의 업무상 재해 인정기준 적용의 검토가 필요할 것으로 사료된다.

\section{연령과 노인성 난청}

나이 자체는 직업적인 소음 노출에 의한 청력손실 정도에 직 접적으로 영향을 미치는 요소는 아니나, 노인성 난청(presbycusis)과 사회성 난청(sociacuisis)의 영향은 나이에 따라 증가하기 때문에 나이도 청력에 간접적인 영향을 미친다. 청력역치 변화 는 초기 청력 상태에 의존하며 나이는 중요한 요소로 작용한 다. 또한 소음 노출 기간에 따른 청력역치의 증가는 선형적이다. 그러나 인간의 연구에서 소음에 의한 청력역치의 증가는 초기 에 빠르고 그 다음에는 느려지며 연령 증가에 따른 청력역치도 증가하며, 고주파역의 역치손실이 저주파역보다 더 크게 나타 난다(Corso, 1980; Lee et al., 2005).

노령화 사회에서 노인성 난청은 고혈압과 관절염 등과 더불 어 가장 발병률이 높은 노인 만성질환 중 하나이며, 연령에 따 라 난청의 발생률이 증가하는 경향을 보이고 있다. 노인성 난청 은 난청이 연령과 관련이 있는 것을 의미하지만 최근의 보고에 서 노인성 난청을 소음 노출로 인한 청력손실, 이독성 약물에 의한 청력손실, 의과 치료와 같은 의과적 장애에 기인한 손실 을 포함하는 여러 종류의 생리학적인 변성의 결과로 나타나는 총체적인 청력손실로 정의하고 있다(Committee on Hearing and Bioacoustics, and Biomechanics, 1988).

연령과 소음 노출 사이의 관계가 가산적인지 상호작용이 있 는지에 대해서는 많은 논란이 있으나, 제한적이지만 가산적이라 는 의견이 많다. 소음 노출과 연령 증가 중 어느 한 요인만 작용 하더라도 어느 정도 청력기관의 병태생리학적인 또는 조직병리 학적인 이상을 초래하기에는 충분하다고 한다. 특히 연령 증가 와 관련된 소음성 난청은 동물실험 결과에서도 소음성 난청의 민감도를 높이는데, 이는 스트레스에 대한 민감도 증가와 스트 레스 후 저하된 조직 회복 속도의 기초가 되는 대사장애와 관 련이 있다.

업무상 질병으로서의 소음성 난청은 감각신경성 난청으로서 비소음성 난청과 먼저 구분하여야 한다. 난청은 청각도를 통해 소음성 난청과 비소음성 난청(특히, 노인성 난청)으로 구별할 수 있다(Coles et al., 2000; Rabinowitz et al., 2006). 소음성 난 청은 일반적으로 $3,4,6 \mathrm{kHz}$ 의 높은 음역대에서 청력손실이 시 작된다. 그리고 $500 \mathrm{~Hz}$ 와 $1 \mathrm{kHz}$ (낮은 음역대) 및 $8 \mathrm{kHz}$ 의 역치 가 3, 4, $6 \mathrm{kHz}$ 보다 낮게 나타난다(Beckett, 2003; Rabinowitz et al., 2006). 이를 일컬어 noise notch라고 한다. 대조적으로, 노 인성 난청의 경우는 높은 음역대로 갈수록 점점 높은 역치를 나 타내는 이른바 경사형의 청각도를 보인다(Beckett, 2003; Coles et al., 2000). 그러나 일반적으로 난청은 노인들에게서 흔히 일 어나는 질환이기 때문에, 고연령에서는 순음청력검사상 청각도 로 소음성 난청과 비소음성 난청(노인성 난청)을 구분하기는 불 가능하다. 소음에 노출되었다 하더라도 연령에 의한 역치 변화 에 소음에 의한 noise notch를 적용하였을 때, 70세 이상 군의 청력도는 소음성 난청의 특성을 보여주지 못한다. 소음의 장기 적 영향에 대해서는 일반적으로 소음 노출 기간이 끝나면 난 청은 더 이상 진행되지 않고 지연성 난청을 초래하지 않는데, 70세 이상 고령자의 청력에서는 소음성 난청보다는 노인성 난 청이 더욱 중요한 역할을 하여 소음성 난청의 역할이 미미하다 (Hederstierna \& Rosenhall, 2016).

그러나 소음 노출력이 길고 직업적 영향이 연령보다 클 경우 업무 관련성 판단은 가능하다. 실제 소음에 의해 손상을 받은 귀는 정상인에 비해 연령 수준보다 빠르게 손상이 나타난다 (Gates et al., 2000). 그리고 특히 젊었을 때 충격음 노출은 4, 6, $8 \mathrm{kHz}$ 에서의 연령에 따른 청력손실을 가속화한다(Xiong et al., 2014). 따라서 소음성 난청과 더불어 부가적인 연령에 의한 청력 손실의 보상기준의 적용에 있어 소음 노출 후 시간 제약 $(1,2,3$, 5 년 등)이나 연령 제한, 노화에 의한 청력손실 효과를 고려하여 25 30 dB을 보정하는 'low fence' 판정 활용, 특정 연령 시점에 서 연령 보정을 적용하고 있다.

ISO-1999(1990)와 미국표준협회(American National Standards Institute) S3.44(1996)에서는 자연적인 청력손실과 소음 에 노출되었을 경우 연령이 증가할수록 나타날 수 있는 청력손 실의 정도를 모델로 제시하고 있다. 다만, 소음으로 인한 난청 은 소음의 음향학적 특성, 노출 기간 등 직업적인 요인과 더불 어 개인의 건강 등 여러 요인에 영향을 받기 때문에 개인차가 있을 수 있음을 유의하여야 한다.

연령의 증가에 따른 청력역치의 상승은 불가피하다. 소음성 난청의 업무상 질병의 판단과 장해심사 시 당해 근로자의 재직 중 직업적으로 소음에 노출되었는가의 여부를 조사하여야 함 과 더불어 소음 노출로부터 경과 또는 정년(이직/전직) 후 연령 증가에 따른 청력의 저하는 필수적으로 고려하여야 할 요소이 다. 이에 장해 고정 이후 오랜 기간이 경과된 상태에서 장해심 사 시 연령대별 보정 또는 일정한 연간 손실률을 감산하여 연 령 증가에 따른 청력역치의 변화량을 고려해 평가하여야 한다.

\section{난청 치유 시기 및 소멸시효}

산업재해보상보험법 시행규칙 제48조 관련 [별표5] 제2호 가 목 1) 라)에서 소음성 난청으로 인한 장해 급여 청구권의 발생 에 관하여, 소음성 난청의 치유 시기를 “더 이상 직업성 난청이 유발될 수 있는 장소에서 업무를 하지 않게 되었을 때”라고 규 정하여, 난청이 유발되는 작업장을 떠난 때로부터 장해 급여 청 
구권이 발생하여 3년의 소멸시효가 진행되는 것으로 보아 근로 복지공단은 $85 \mathrm{~dB}$ 미만 작업장을 비소음부서(보상 6602-542, 2000.5.9.)로 보고 $85 \mathrm{~dB}$ 이하 작업장으로 전환 배치되거나 작업 장 소음이 $85 \mathrm{~dB}$ 이하로 된 지 3년이 경과하여 산재를 신청하 면 '소멸시효 완성'을 이유로 불승인하였다. 이후 법원의 판단으 로 공단은 '당해 근로자가 근무하는 작업환경의 변화 및 청력 손실의 진행 여부를 고려하여 실질적으로 비소음부서로 전환 했는지 여부'(보상부-4856, 2013.9.6.)로 변경하였다. 이후 치유 시기 해석에서 비소음부서에서 근무한 이후 3 년이 지나 소음성 난청을 진단받아 신재 신청을 하면 이 또한 소멸시효를 이유로 기각하여 이에 대한 공단의 해석은 대법원에서 위법한 것으로 판단하였다. 소음성 난청은 소음으로부터 벗어난다고 해서 치 료되지 않고 단지 악화를 방지할 뿐이며, 현재의 의료 수준으로 는 치료할 방법이 없으므로 치료의 효과를 더 이상 기대할 수 없는 상병의 증상이 있음을 확진받은 시점에 그 증상이 고정된 상태에 이르렀다고 볼 수 있고, 이는 법령의 규정에 따른 '치유 시점'이라 판시하여 직업성 난청의 치유 시기를 '직업성 난청이 유발될 수 있는 작업장을 떠난 때'가 아닌, '직업성 난청의 증상 이 있음을 확진받은 때'로 보고, 이때 장해 급여 청구권이 발생 하고, 이때부터 소멸시효가 진행한다고 보았다(대법원 2014.9.4. 선고 2014두7374 판결). 이에 공단의 기존 규정은 2016년 3월 28일 개정으로 삭제되었다.

고용노동부와 공단은 2016년 1월에 '소음성 난청 업무처리기 준을 통해 기존 행정 해석을 변경하여 소음성 난청 진단일의 의미를 "보험급여 지급 대상이 된다고 확인될 당시에 발급된 진 단서나 소견서 발급일로 바꽀다.

2014년 대법원의 판결이 있기 전까지 이 사건 규정이 존재하 였고, 장해 급여를 청구할 수 없는 '법률의 존재’라는 법률상의 장애로 "소음성 난청 장해보상청구권은 소음부서를 떠난 후 3 년 이내에 행사해야 한다”고 하여 퇴직(이직) 후 3년이 지나서 발병하는 소음성 난청 사례에 대하여 일절 보상을 거부하는 행 정관행을 형성하였다. 그러나 위 대법원 판결로 이 사건 규정에 대한 무효 판단이 있은 때에 비로소 법률상의 장애가 제거되어 그때부터 소멸시효가 진행한다라고 보아 논란이 되고 있다.

\section{CONCLUSIONS}

소음성 난청은 전형적으로 $3 \sim 6 \mathrm{kHz}$ 의 고음역의 청력손실이 큰 양측성의 감각신경성 난청이다. 소음성 난청의 업무상 질병 의 인정은 $85 \mathrm{~dB}(\mathrm{~A})$ 의 소음 노출 수준과 3 년의 노출 기간, 기 도-골도 청력의 차이가 없는 감각신경성 난청으로서 난청 유형, 그리고 노인성 난청 등 배제되는 난청 질환을 규정하여 판단하 고 있다. 특히, 소음의 직력이 인정됨에도 소음성 난청과 고연령
으로 인한 노인성 난청의 영향을 구분하기 어려워 소음성 난청 의 인정 등 업무상 질병으로서 관련성을 무시할 수 있다. 그리고 $85 \mathrm{~dB}(\mathrm{~A})$ 이하의 비소음 작업장으로 전환 배치되어 3년이 경과 하여 산재를 신청하면 소멸시효 완성을 이유로 불승인을 하였 다. 그러나 이와 같은 장해 급여 청구권의 발생과 관련한 소멸 시효는 대법원 판례에 따라 최근에 난청의 확진일로 바뀌었다. 이 연구는 이와 같은 소음성 난청의 업무상 질병 인정 기준과 업무상 질병의 판정 및 장해 판정과 관련한 법적 근거로써 소 음 노출 기준과 소음 노출 평가방법, 소음성 난청의 업무상 질 병의 판정을 위한 난청의 유형 평가 및 장해 급여 청구에 따른 제반 문제에 대해 고찰하고 제언하였다.

중심 단어 : 소음·소음성 난청·소음 노출기준·소음 노출 평가· 노인성 난청.

\section{REFERENCES}

ACOEM Task Force on Occupational Hearing Loss, Kirchner, D. B., Evenson, E., Dobie, R. A., Rabinowitz, P., Crawford, J., et al. (2012). Occupational noise-induced hearing loss: ACOEM Task Force on occupational hearing loss. Journal of Occupational and Environmental Medicine, 54(1), 106-108.

American National Standards Institute. (1996). ANSI S3.44: Determination of Occupational Noise Exposure and Estimation of Noise-Induced Hearing Impairment. New York, NY: Acoustical Society of America.

Beckett, W. S. (2003). Noise induced hearing loss. Journal of Occupational and Environmental Medicine, 45(10), 1029; author reply 1029.

Coles, R. R., Lutman, M. E., \& Buffin, J. T. (2000). Guidelines on the diagnosis of noise-induced hearing loss for medicolegal purposes. Clinical Otolaryngology and Allied Sciences, 25(4), 264-273.

Committee on Hearing, Bioacoustics, and Biomechanics, Commission on Behavioral and Social Sciences and Education, National Research Council. (1988). Speech understanding and aging. Working group on speech understanding and aging. The Journal of the Acoustical Society of America, 83(3), 859-895.

Corso, J. F. (1980). Age correction factor in noise-induced hearing loss: a quantitative model. Audiology, 19(3), 221-232.

Gates, G. A., Schmid, P., Kujawa, S. G., Nam, B., \& D’Agostino, R. (2000). Longitudinal threshold changes in older men with audiometric notches. Hearing Research, 141(1-2), 220-228.

Hederstierna, C. \& Rosenhall, U. (2016). Age-related hearing decline in individuals with and without occupational noise exposure. Noise and Health, 18(80), 21-25.

Industrial Accident Compensation Insurance Act. (2016). Occupational Diseases Criteria. Presidential Decree 27751.

International Organization for Standardization. (1990). ISO 1999: Acoustics-Determination of Occupational Noise Exposure and Estimation of Noise-Induced Hearing Impairment. Geneva: ISO.

Kawata, S. \& Suga, F. (1967). Industrial sudden deafness. The Annals of Otology, Rhinology, and Laryngology, 76(4), 895-902.

Kim, K. S., Kim, J., \& Park, K. (1998). Sudden sensorineural hearing loss caused by noise exposure to intense sound. Korean Journal of Occupational and Environmental Medicine, 10(4), 618-626.

Kim, K. S., Park, M. S., \& Kang, S. K. (2002). Atypical noise-induced hearing loss as a workers' impairment criteria. Korean Journal of Occupational and Environmental Medicine, 14(3), 334-345.

Kim, K. S., Yoo, S. W., Hong, K. H., Jang, S. J., Yun, Y. H., \& Byun, K. W. (2011). Cases on work-related hearing loss due to noise exposure. Audi- 
ology and Speech Research, 7(1), 89-99.

Lacerda, A., Quintiliano, J., Lobato, D., Gonçalves, C., \& Marques, J. (2015). Hearing profile of brazilian forestry workers' noise exposure. International Archives of Otorhinolaryngology, 19(1), 22-29.

Lee, F. S., Matthews, L. J., Dubno, J. R., \& Mills, J. H. (2005). Longitudinal study of pure-tone thresholds in older persons. Ear and Hearing, 26(1), $1-11$.

Lyons, G. D., Dodson, M. L., Casey, D. A., \& Melancon, B. B. (1978). Round window rupture secondary to acoustic trauma. Southern Medical Journal, 71(1), 71-73.

Ministry of Employment and Labor. (2016). Exposure Limits for Chemical Substances and Physical Agents (MoEL Public Notice No. 2016-41).

Ministry of Employment and Labor. (2016). Notice on measurement and evaluation of working environment (MoEL Public Notice No. 2016-39).

National Hearing Conservation Association. (2011). NHCA Guidelines for Recording Hearing Loss on the OSHA 300 Log.

National Institute for Occupational Safety and Health. (1998). Criteria for a Recommended Standard Occupational Noise Exposure. Cincinnati, $\mathrm{OH}$ : NIOSH Publications.

Occupational Safety and Health Research Institute, KOSHA. (2016). Practice Guidelines for Workers' Health Examination. Volume 2. Special Health Examination Methods by Hazardous Factors. 2016-OSHRI-276.

Park, S. J., Sung, J. H., Sim, C. S., Yun, S. H., Yeom, J. H., Kwon, J. K., et al. (2016). Comparisons of hearing threshold changes in male workers with unilateral conductive hearing loss exposed to workplace noise: a retrospective cohort study for 8 years. Annals of Occupational and Environmental Medicine, 28, 51.

Pullen, F. W. II., Rosenberg, G. J., \& Cabeza, C. H. (1979). Sudden hearing loss in divers and fliers. Laryngoscope, 89(9 Pt 1), 1373-1377.

Rabinowitz, P. M., Galusha, D., Dixon-Ernst, C., Clougherty, J. E., \& Neitzel, R. L. (2013). The dose-response relationship between in-ear occupational noise exposure and hearing loss. Occupational and Environmental Medicine, 70(10), 716-721.

Rabinowitz, P. M., Galusha, D., Dixon-Ernst, C., Slade, M. D., \& Cullen, M. R. (2007). Do ambient noise exposure levels predict hearing loss in a modern industrial cohort? Occupational and Environmental Medicine, 64(1), 53-59.

Rabinowitz, P. M., Galusha, D., Slade, M. D., Dixon-Ernst, C., Sircar, K. D., \& Dobie, R. A. (2006). Audiogram notches in noise-exposed workers. Ear and Hearing, 27(6), 742-750.

Savolainen, S. \& Lehtomäki, K. M. (1997). Impulse noise and acute acoustic trauma in Finnish conscripts. Number of shots fired and safe distances. Scandinavian Audiology, 26(2), 122-126.

Shim, C. G., Roh, J. H., \& Park, J. G. (1995). A comparison of noise level by noise measuring methods. Journal of Korean Society of Occupational and Environmental Hygiene, 5(2), 128-136.

Stephenson, M. R., Nixon, C. W., \& Johnson, D. L. (1980). Identification of the minimum noise level capable of producing an asymptotic temporary threshold shift. Aviation, Space, and Environmental Medicine, 51(4), 391-396.

Xiong, M., Yang, C., Lai, H., \& Wang, J. (2014). Impulse noise exposure in early adulthood accelerates age-related hearing loss. European Archives of Oto-Rhino-Laryngology, 271(6), 1351-1354.

Ylikoski, J. (1989). Acute acoustic trauma in finnish conscripts. Etiological factors and characteristics of hearing impairment. Scandinavian Audiology, 18(3), 161-165. 